\title{
Does Recognition Versus Disclosure Really Matter? \\ Evidence from the Market Valuation of Recognition of Employee Stock Option Expenses ${ }^{\#}$
}

\author{
Flora Niu and Bixia $\mathrm{Xu}$
}

Wilfrid Laurier University, Canada

\begin{abstract}
This paper examines the market valuation of employee stock option expenses recognized by using the fair value approach under the Canadian Institute of Chartered Accounts Handbook section (CICA HB) 3870. Based on a sample of Canadian public firms traded on the Toronto Stock Exchange (TSX), we find that investors value employee stock option expenses differently prior to and after the implementation of the new standard. Specifically, pro forma compensation expenses disclosed prior to the new accounting regulation are negatively associated with annual stock returns, suggesting that the market interprets these expenses to have negative valuation consequences. In contrast, recognized stock option expenses from using the fair value approach mandated by the HB 3870 are positively associated with stock returns, indicating that the market now interprets these expenses as a type of "asset" that contributes positively to firm valuation. Overall, the evidence suggests that the mandatory expensing of employee stock options increases the perceived quality of financial statements and mitigates the perception that firms use stock options opportunistically. Consequently, the market is able to translate the incentive effect of employee stock options into firm value.
\end{abstract}

JEL Classifications: G14, G18, M48

Keywords: Employee stock options, market valuation, recognition, disclosure

*Corresponding author: Email: fniu@wlu.ca. Tel: (519) 884-0710 ext. 3293. Fax: (519) 884-0201. Address: School of Business and Economics, Wilfrid Laurier University, Waterloo, ON, Canada N2L 3C5.

${ }^{\#}$ We are grateful to the Canadian Institute of Chartered Accountants/Canadian Academic Accounting Association's Research Grant Program for project funding. Niu also acknowledges research funding from CA/ Laurier Centre for the Advancement of Accounting Research and Education. We would like to thank Thomas Carment, Daniel Cohen, Robert Mathieu and Devan Mescall and participants at the American Accounting Association (AAA) 2007 conference, the Canadian Academic Accounting Association (CAAA) 2007 conference and the 2008 Asia-Pacific Journal of Accounting and Economics (APJAE) Symposium for useful comments.

Data availability: data used for this study are obtained from publicly available sources. 


\section{Introduction}

This paper examines the market valuation of stock option expenses recognized by using the recognition rules under the CICA HB section 3870: Stock-Based Compensation and Other Stock-Based Payments. We investigate two research questions in this study. We initially ask whether investors' response to stock-based compensation expenses depends on where this information is placed - disclosure in the notes or formal recognition on the income statements. We next examine whether there is any incremental information content related to the recognition of stock option expenses under the new expensing requirement of HB 3870.

While the importance of employee stock options (ESOs) is well justified in the literature, the accounting issues and the resulting implications for equity valuation are largely controversial. The central focus of this controversy is whether the cost of ESOs should be recognized on the income statement or disclosed in the notes to the financial statements. Some argue that stock options have value since they are used to motivate performance (i.e. to generate profits). Furthermore, they have a dilutive effect on the existing shares of the company, and thus are costly to the company. Accordingly, the value of the transferred ownership should be recognized as an expense on the income statement. Indeed, Aboody (1996) finds a significantly negative association between his measure of cost of ESOs based on a modified option pricing model and stock price, indicating that the capital market perceives the cost of ESOs as an expense. Similarly, Core et al. (2002) provide evidence on the dilutive effects of ESOs. Consistent with these findings, regulatory bodies such as the Accounting Standard Board (AcSB) in Canada, the Financial Accounting Standard Board (FASB) in the USA, and the International Accounting Standards Board (IASB) believe that the expensing treatment can enhance financial reporting transparency and restore investors' confidence, and have required firms to recognize ESO costs on the income statement.

Despite regulatory changes opponents, on the other hand, argue that mandatory recognition is not necessary since firms have been required to disclose ESO costs in the notes and must show the potential effects of these costs on earnings. More seriously, the mandatory expensing can compromise the financial reporting quality due to the lack of a reliable ESO pricing model. Related to this line of research, several studies (e.g. Aboody et al., 2006; Balsam et al., 2003; Johnston, 2006) find evidence that managers appear to understate the expense of ESOs under FAS123 for earnings management purposes. Therefore, whether recognition of these costs can indeed enhance the financial reporting quality remains an open question, as the estimation of ESO costs involves managerial discretion.

We contribute to this debate by examining whether the stock option expenses recognized by using the Canadian accounting standard (i.e. CICA HB 3870) are incrementally useful to financial statement users. By doing so, we shed light on whether the expensing requirement improves the financial reporting quality. Using a sample of Canadian public firms with available data of stock option expenses (disclosed and recognized) prior to and after the implementation of the fair value approach during the years 2003-2005, we find that pro forma compensation expenses disclosed prior to the new accounting regulation are significantly negatively associated with annual 
stock returns. In contrast, recognized stock option expenses, by using the fair value approach, are significantly positively associated with stock returns, indicating that the market now interprets these expenses as a type of "asset" that contributes positively to firm valuation. Overall, the evidence suggests that the mandatory expensing of ESOs increases the perceived quality of financial statements and mitigates the perception that firms use stock options opportunistically. Consequently, the market is able to translate the incentive effect of ESOs into firm value.

Our findings shed light on a timely and controversial financial reporting issue from a valuation perspective. The results from this study suggest that the expensing requirement for stock options improves the capacity of financial statements to explain firm values. The evidence has important implications for standard setters internationally. We provide feedback to the AcSB about the effectiveness of the new standard, which facilitates the improvement of financial reporting in Canada. The results are also useful to the IASB in its process of refining the international accounting standard for ESOs.

In addition, the study contributes to the literature on the recognition and the disclosure treatments of accounting information, by identifying how financial statement users process disclosures and whether the recognition is an appropriate substitute for the disclosure. Although there is no consensus that consequences and value relevance can be used as objective metrics to determine preferability of accounting standards (Bernard and Schipper, 1994), our research provides input to regulators on recognition and measurement issues related to ESOs.

The rest of the paper is organized as follows. Section 2 presents the background information about accounting for stock-based compensation in Canada. Section 3 discusses prior research and develops hypotheses, and section 4 describes the research design and sample selection process. Section 5 presents the empirical results, and section 6 concludes.

\section{Accounting for Stock-Based Compensation in Canada}

The Canadian financial disclosure regime provides a unique setting for testing the market valuation of recognized stock option expenses for the following reasons.

First, there are some important differences in the use of stock options between Canada and the United States. Academic studies (e.g. Klassen and Mawani, 2000) demonstrate that stock options are used to varying degrees across the two countries due to different tax treatments. In addition, option dilution remains lower in Canada since Canada has fewer large high tech companies and more family-owned public companies (McFarland, 2002). Furthermore, in Canada, the option dilution is not permitted to exceed $10 \%$ under the proxy voting standards of many major investor groups. These differences imply that findings from prior research addressing the materiality and value relevance of stock option expenses disclosed under FAS123 based on US companies may not be generalizable to Canadian firms.

Second, Canada is the first country to mandate the recognition of ESO costs. HB 3870 sets the standards for the recognition, measurement and disclosure of stock-based compensation. In the past, HB 3870 followed the FAS123, in which the practice of 
expensing stock options using the fair value method was encouraged on a voluntary basis. Companies that elected not to use the fair value approach were required to disclose the (pro forma) impact of ESOs on earnings per share as if this method had been used. During 2003, in response to pressure from the investment community regarding the appropriate accounting treatment for ESOs, the AcSB amended the recognition treatment and eliminated companies' ability to choose when reporting stock options. Effective for fiscal years beginning on or after January 1, 2004, all public Canadian companies are required to recognize stock option compensation expenses using the fair value method. Under the amended CICA section 3870, if companies recognize the cost of ESOs granted in the current year, they are still required to disclose the pro forma impact of options granted in prior years. ${ }^{1}$ In contrast, the FASB issued FAS123(R) in 2004, which requires public firms to recognize the fair value of stock option grants as a compensation cost in their financial statements, effective for fiscal periods beginning after June 15, 2005. This research allows us to provide some early evidence on the effectiveness of the new regulation standards.

Finally, in the US, prior to the issuance of FAS123(R), more than 700 firms had elected to expense ESOs costs voluntarily; research has been conducted to examine accounting issues related to this voluntary behavior (e.g. Aboody et al., 2004a). A study by a consulting firm, Oxford Metrica, however, indicates a selection bias of these firms, and the market reacts suspiciously to this self-servicing behavior. ${ }^{2}$ Therefore, an examination of the market reaction to the mandatory recognition of ESO costs in the Canadian context allows us to shed light on this issue more effectively.

\section{Related Research and Theoretical Framework}

\subsection{Related Research}

Prior and ongoing studies in the literature focus on the valuation issues and implications of accounting for ESOs along several dimensions using US data. Several studies examine the lobby behavior prior to the issue of FAS123, and find that concerns regarding executive compensation appear to motivate lobby behavior relating to accounting for ESOs. Dechow et al. (1996) present evidence that lobbying against the SFAS 123 Exposure Draft is related to the relative amount of stock option compensation paid to top executives. Similarly, Hill et al. (2002) find that lobbying against disclosure of stock option compensation information proposed by the FASB is positively related to stock compensation paid to the top five executives.

Another line of research focuses on the information content of pro forma disclosures under FAS 123. However, the evidence is mixed. Using an instrumental variable approach, Aboody et al. (2004b) find stock options are viewed as an expense and

\footnotetext{
${ }^{1}$ A review of the TSX 60 firms' financial statements for the first quarter of 2004 indicates that many firms have chosen to adopt the fair value method prospectively.

${ }^{2}$ The majority of firms that elected to expense ESO costs voluntarily are those with less negative impact of ESOs on earnings. See "Voluntary expensing on the decline after a mixed market response" by Oxford Metrica.
} 
are negatively associated with share price. Likewise, Li (2003) finds that FAS123 disclosures provide useful information for estimating the effects of employee options on equity value. In contrast, several other studies find evidence that stock options provide a mechanism for managers to manage earnings. For example, Aboody et al. (2006) find that managers manipulate stock option compensation expenses in order to avoid political costs related to executive compensation. Overall, these prior studies shed light on the value relevance or the reliability of pro forma ESO disclosures; they are silent on whether the recognition treatment provides an improved treatment for ESOs.

Several other studies examine the stock market reactions to voluntary announcements of expensing stock options made by US firms (e.g. Aboody et al., 2004a; Ferri et al., 2005; Balsam et al., 2006; Bartov and Hayn, 2008). More recent studies (e.g. Balsam et al., 2008; Choudhary et al., 2009) examine the market reactions to firms that accelerated the vesting of some or all of their ESOs in advance of adopting FAS123R. Again, the evidence from these studies provides limited insight into the recognition versus disclosure issue due to the self-selection problem of the sample firms.

\subsection{Theoretical Framework}

In this study, we first examine the value relevance of the disclosed pro forma expense as measured using the fair value method prior to the new standard. The evidence from prior studies generally suggests that the disclosed amounts are perceived as expenses, and are value relevant and incorporated into share prices. Two important factors, however, suggest that the impact of ESO expenses on firm value may not be the same as other operating expenses. First, option plans can be very effective to motivate corporate managers. Although the proposed accounting treatment fails to reflect this long-term "intangible" effect on the financial statements, the market may implicitly appreciate this effect. ${ }^{3}$ Second, previous research indicates that managers may understate expenses for earnings management purposes. If the market anticipates this discretion, the weights put on the option expenses may be less than those on other expenses that are less likely to be subject to earnings manipulations. The observed market pricing of the disclosed ESO expenses will add to our understanding of the value of disclosed information.

To examine whether recognition adds value, our second objective is to examine the usefulness of recognized stock option expenses after the implementation of the new standard. If the market is efficient, in theory there should be no difference between the informativeness of recognized information and that of disclosed information. Regulators and researchers believe that market participants value substance over form and hence, where the information is presented would not matter. However, Bernard and Schipper (1994) argue that if market participants view footnote disclosures as being less reliable or are not sophisticated enough to make appropriate adjustments, they will likely assign more importance to recognized financial statement items, and this will manifest itself in greater value relevance. Indeed, researchers have provided supporting evidence that the method of presentation in the financial statements does matter, depending on who uses the financial statements and how naive they are in interpreting footnote disclosures

\footnotetext{
${ }^{3}$ In Canada, no tax deduction is allowed for ESOs at the employer level (Mawani, 2003). Therefore, firms need to carefully weigh the benefits versus the costs of awarding options when they consider ESO plans.
} 
(Imhoff et al., 1993, 1995). Corporations' lobby behavior against the exposure draft of expensing stock options also suggests that managers have concerns that investors may become functionally fixated to recognized earnings, and consequently expensing could directly affect stock prices. The above discussion indicates that the recognized expense would be more value relevant than the pro forma information disclosed in the notes. The recognition of an item in the financial statements, however, introduces the measurement issue. Critics have raised the concerns that fair values of stock options may not be reliably measured. The reliability concerns imply that the valuation impact of recognition may not be obvious. Therefore, it is an empirical question as to whether the market perceives the recognition of stock option expenses as incrementally useful.

\section{Research Design and Sample Selection}

\subsection{Research Design}

We adopt the following long window earnings capitalization model to conduct the tests:

$$
R_{i t}=\alpha_{0}+\alpha_{1} E_{i t}+\varepsilon_{i t}
$$

where:

$R_{i t}=$ raw annual stock equity return for firm $i$ in year $t$

$E_{i t}=$ earnings for firm $i$ in year $t$

To examine whether the disclosed pro forma expenses related to stock option awards are incrementally useful for market valuation prior to the new accounting standards, we estimate the following modified version of equation (1):

$$
R_{i t}=\alpha_{0}+\alpha_{1} E_{i t} V_{R E S O X}+\alpha_{2} D_{E S O X}+\alpha_{3 t} \text { VRESOXit }+\alpha_{4} O E X_{i t}+\varepsilon_{i t}
$$

In equation (2), DESOX ${ }_{i t}$ refers to disclosed pro forma stock option expenses for firm $i$ in year $t$. Under the alternative hypothesis that pro forma stock option costs are viewed as expenses, we predict that $\alpha_{2}<0$. To shed light on whether the market appreciates the intangible feature of options, we include $O E X_{i t}$, which refers to several variables representing operating expenses (e.g. research and development (R\&D) expenses and other operating expenses), and we predict that the multiple on pro forma amounts will be less than that on other operating expenses. That is, we predict that $\alpha_{2}<\alpha_{4}$. Since some Canadian firms voluntarily expense ESOs prior to the proposed accounting standards, we use VRESOEX ${ }_{\text {it }}$ to represent stock option expenses recognized by using the fair value approach for firm $i$ in year $t$ if firm $i$ chooses to do so. ${ }^{4} E_{i t-} V R E S O X_{i t}$ refers to earnings

\footnotetext{
${ }^{4}$ We assign a value of zero to this variable for a firm that still uses the pro forma disclosure instead of voluntary recognition of ESO expenses.
} 
from operations for firm $i$ in year $t$, before stock option expenses recognized by using the fair value approach (if applicable) and other operating expenses $\left(O E X_{i t}\right)$.

$R_{i t}$ is the twelve months' raw stock returns ending three months after the fiscal year end. All independent variables are deflated by beginning-of-period share price. Data are collected for 2003, as firms are required to disclose pro forma information for options awarded after January 2002.

To achieve our second research objective, we use the following model to examine the value relevance of the recognized ESO expenses after the new recognition requirement:

$$
R_{i t}=\alpha_{0}+\alpha_{1} E_{i t-} R E S O X_{i t}+\alpha_{2} \operatorname{RESOX}_{i t}+\alpha_{3} O E X_{i t}+\varepsilon_{i t}
$$

In equation (3), RESOX refers to the recognized expenses for ESOs under the mandatory recognition requirement. To provide insight about the value relevance of the recognition of ESO compensation expenses following the CICA requirement, we partition our sample based on the degree to which a firm's financial performance is potentially influenced by the new accounting requirement. High-growth firms may be significantly affected by the expensing requirement, since ESOs provide these firms with an opportunity to offer employees a compensation package that does not require large amounts of cash in the short term. Thus, we use the market-to-book ratio at the year end to partition sample firms into high-growth and low-growth sub-groups. In addition, firms of different sizes and in different industries may be affected by the reporting requirement differently. To incorporate this possibility into the research design, we also partition firms by firm size (logarithm of total assets) and industry classification (high tech and financial institutions versus regular firms). The complete empirical regression is shown below:

$$
\begin{aligned}
R_{i t}= & \alpha_{0}+\alpha_{1} E_{i t} R_{E} \text { SSOX }_{i t}+\alpha_{2} \text { RESOX }_{i t}+\alpha_{3} \text { RESOX }_{i t} * G R O W \\
& +\alpha_{4} \text { RESOX }_{i t}{ }^{*} \operatorname{SIZE}+\alpha_{5} \text { RESOX }_{i t} * \text { INDU }+\alpha_{6} \text { OEX }_{i t}+\varepsilon_{i t}
\end{aligned}
$$

In equation (4), GROW is an indicator, 1 if market-to-book ratio at the year end is above the sample median, and 0 otherwise. SIZE is an indicator, 1 if the logarithm of total assets at the year end is above the sample median and 0 otherwise. INDU is an indicator, 1 for high tech firms and 0 otherwise. Following Espahbodi et al. (2002), high tech firms are those with four-digit SIC codes of 3570-3579, 3660-3669, 3670-3679, 3690-3699, 4800-4899, 8730-8734, namely, computer, electronics, semi-conductors, biological research, communications, and similar firms. Prior research indicates that financial institutions often use stock option plans, and thus may be significantly influenced by the accounting treatment. We also include financial institutions (SIC codes of 6000-6999) in the high tech group.

All the indicator variables are entered as the interactive variables with the recognized compensation expense variable (RESOX). All other variables in equation (4) are as defined previously. The sample period for this analysis starts from 2004, the year when firms are required to recognize for the first time the compensation expenses relating to options, and ends in 2005. Under the alternative hypothesis that recognition is information useful, we predict that $\alpha_{2}$ is non-zero. 


\subsection{Sample Selection}

The analyses are conducted based on a sample of Canadian public companies traded on the TSX that comprise of the S\&P/TSX composite index for the years 2003-2005. Stock option granting information, including recognized compensation expenses starting from 2004, and pro forma stock option expense disclosures after January 2002 for the entire group of sample firms, are collected from their annual reports. To be included in the sample, financial data must be available from FPinfomart.ca. Stock market performance data are collected from the Canadian Financial Markets Research Centre (CFMRC). We eliminate sample firms whose financial statements cannot be located from SEDAR or MERGENT Online, which do not offer a stock option plan for the year, which are acquired by or merged with another company during the year, and which do not have the required financial data for the regression variables. We convert stock option data originally presented in US dollars into Canadian dollars. The final sample consists of 569 firm-year observations for the period of 2003-2005 (202 firms for year 2003, 189 firms for 2004 and 178 firms for 2005).

\section{Results}

\subsection{Test of Information Content of Disclosures and Recognition}

Table 1 presents descriptive statistics for the 2003 sample. Panel A presents selected firm financials in raw amounts. During the year 2003, while 91 firms continue to disclose pro forma amounts of compensation expenses related to the ESO plan as required, 111 firms voluntarily expense stock options by using the fair value approach, and thus recognize a compensation expense as a part of the income statement. Of these 111 firms, 53 use the prospective application approach to apply the fair value method; thus, as required, they must disclose pro forma expenses related to options granted in prior years. Sample firms, on average, report an operating net income of $\$ 0.169$ million $(O P I N)$, and expensing firms report an ESO expense of $\$ 0.460$ million $(B L V)$, lower than their disclosing counterparts of $\$ 0.836$ million $(P F E)$. Other operating expenses reach the highest expense record of $\$ 6.171$ million (MISE), leaving R\&D expenses the second highest of $\$ 1.955$ million $(R D E)$.

Panel B shows the descriptive statistics for the regression variables used in equation (2). To minimize the impact of extreme variables on the regression estimates, variables in Panel B are winsorized at the top 99th percentile and the bottom of the first percentile. As shown in Panel B, raw annual stock returns for the sample firms on average are 0.382; with a median of 0.252 . The median value of recognized ESO expenses is 0.003 , and the corresponding value for the disclosed pro forma ESO expenses is 0.038. 
Table 1

Descriptive Statistics - 2003 Sample

Panel A: Descriptive Statistics for Selected Raw Data for Year 2003 Sample Firms (in Millions CAN\$)

\begin{tabular}{lccccc}
\hline \multicolumn{1}{c}{ Variable } & Mean & Median & Std. Dev. & $25 \%$ & $75 \%$ \\
\hline OPIN & 0.169 & 0.082 & 0.226 & 0.003 & 0.242 \\
\hline$B L V$ & 0.460 & 0.400 & 0.311 & 0.193 & 0.735 \\
\hline$P F E$ & 0.836 & 0.000 & 2.755 & 0.000 & 0.613 \\
\hline MISE & 6.171 & 0.840 & 20.449 & 0.000 & 3.460 \\
\hline$R D E$ & 1.955 & 0.000 & 7.645 & 0.000 & 0.061 \\
\hline
\end{tabular}

Panel B: Descriptive Statistics for Regression Variables Used in Equation (2)

\begin{tabular}{lccccc}
\hline \multicolumn{1}{c}{ Variable } & Mean & Median & Std. Dev. & $25 \%$ & $75 \%$ \\
\hline Ret & 0.382 & 0.252 & 0.865 & 0.051 & 0.577 \\
\hline$E$ & 23.177 & 10.319 & 30.436 & 3.941 & 28.247 \\
\hline VRESOX & 0.182 & 0.003 & 0.936 & 0.000 & 0.085 \\
\hline DESOX & 0.184 & 0.038 & 0.339 & 0.000 & 0.192 \\
\hline OEX_MISE & 13.153 & 0.000 & 29.017 & 0.000 & 6.379 \\
\hline OEX_RDE & 1.028 & 0.000 & 4.432 & 0.000 & 0.000 \\
\hline
\end{tabular}

Notes:

Sample is for 202 Canadian S\&P/TSX composite index firms for year 2003.

Variables are defined as follows:

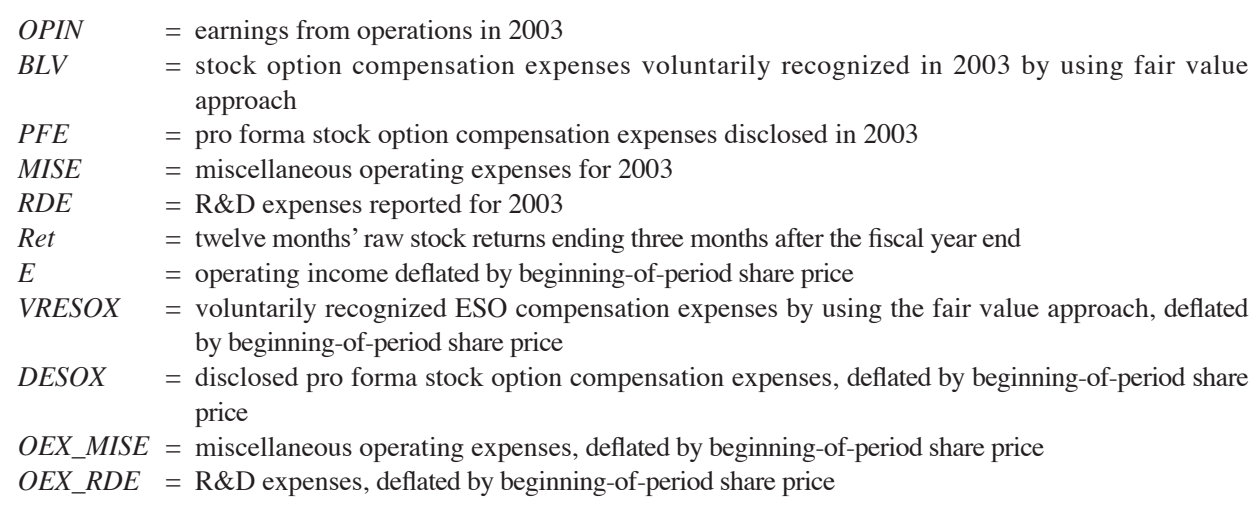

The correlations among variables in equation (2) are reported in Table 2. As expected, there is a positive association between the measure of operating income and stock returns, which is significant at the $1 \%$ level. Stock return is negatively correlated with disclosed option expenses at the $10 \%$ level. Surprisingly, there is no significant association between stock returns and recognized option expenses. Consistent with prior studies (Lev and Sougiannis, 1996; Chan et al., 2001), stock return is positively 
correlated with R\&D expenses at the $1 \%$ level, while it is not significantly correlated with other operating expenses.

Table 2

Correlation Matrix - 2003 Sample

\begin{tabular}{lcccccc}
\hline \multicolumn{1}{c}{ Variable } & Ret & $E$ & VRESOX & DESOX & OEX_MISE & OEX_RDE \\
\hline Ret & 1 & $0.089 *$ & $0.092 *$ & -0.042 & -0.090 & 0.017 \\
\hline$E$ & $0.232 * * *$ & 1 & 0.118 & 0.021 & 0.051 & $-0.124 * *$ \\
\hline VRESOX & 0.012 & $0.307 * * *$ & 1 & $-0.361 * * *$ & 0.061 & $-0.161 * *$ \\
\hline DESOX & $-0.069 *$ & $0.241^{* * *}$ & -0.067 & 1 & 0.107 & $0.212^{* * *}$ \\
\hline OEX_MISE & -0.011 & $0.291 * * *$ & 0.005 & 0.098 & 1 & $0.288^{* * *}$ \\
\hline OEX_RDE & $0.245^{* * *}$ & -0.007 & -0.041 & $0.119 * *$ & 0.028 & 1 \\
\hline
\end{tabular}

\section{Notes:}

Sample is for 202 Canadian S\&P/TSX composite index firms for year 2003.

Pearson correlations are presented in the lower diagonal and Spearman correlations are presented in the upper diagonal.

$*, * *, * * *$ significant at the $0.01,0.05$ and 0.10 level (two-tailed), respectively.

Variables are defined as follows:

Ret $=$ twelve months' raw stock returns ending three months after the fiscal year end

$E \quad \quad=$ operating income deflated by beginning-of-period share price

VRESOX = voluntarily recognized ESO compensation expenses by using the fair value approach, deflated by beginning-of-period share price

DESOX = disclosed pro forma stock option compensation expenses, deflated by beginning-of-period share price

$O E X \_M I S E=$ miscellaneous operating expenses, deflated by beginning-of-period share price

$O E X \_R D E=R \& D$ expenses, deflated by beginning-of-period share price

Regression results for estimating equation (2) are summarized in Table 3. As expected, there is a significant positive association between returns and earnings from operations before any compensation expenses recognized by firms voluntarily expensing stock options (E_VRESOX). Across all model variations from columns (2) to (5), the disclosed ESO compensation expense (DESOX) is entered into the regression as a negative value; the finding suggests that the market interprets the ESO expense as an expense similar to the interpretation of other operating expenses. Consistent with Aboody et al. (2004a), the coefficient on recognized compensation expenses (VRESOX) is still negative, but statistically insignificant. This finding suggests that voluntary recognition of ESOs has, to some extent, mitigated the negative perception of using and reporting ESOs; thus, it is interesting to further examine whether mandatory recognition would provide incremental information content to the market, a research question that is explored in the next subsection.

As expected, other operating expenses (OEX_MISE) are negatively associated with market returns. Another interesting finding from Table 3 is that the coefficient on 
operating $\mathrm{R} \& \mathrm{D}$ expenses $\left(O E X \_R D E\right)$ is positive and statistically significant, a result that is consistent with prior research (e.g. Lev and Sougiannis, 1996, 1999), which shows that the market compensates for an extra-market risk factor associated with R\&D.

T-tests are conducted to examine the equality of the coefficients on DESOX, VRESOX,OEX_MISE and OEX_RDE. Test results (unreported) indicate that $\alpha_{2}$ is more negative than $\alpha_{3}(t=-2.14), \alpha_{4}(t=-2.58)$ and $\alpha_{5}(t=-2.86)$ at the 5\% level. The evidence suggests that the market interprets the pro forma stock option disclosures as a significant type of expense, which is reflected in firm market valuation. In contrast, the voluntary recognition of compensation expenses prior to the mandatory requirement does not carry significantly negative weight in investors' valuation of the sample firms. Overall, the evidence is inconsistent with Balsam et al. (2006) who find that the market values the cost associated with ESOs as an expense, regardless of whether the quarterly option expense is only disclosed in the notes, or it is also recognized in the income statement voluntarily under FAS148. Our findings suggest that the market does value the cost associated with ESOs as an expense if it is disclosed; recognition of ESO expenses, however, mitigates the negative impact of stock options in firm valuation. As previously discussed, the analysis on market valuation of recognized ESO expenses is based on sample firms who choose to recognize stock option expenses voluntarily. It might be possible that the market does not react significantly to the voluntary recognition due to the self-selective incentive of these firms. The next subsection, therefore, explores whether the market values mandatory recognition of ESO costs differently under the new reporting requirement.

Table 3

Test of Information Content of Pro Forma Stock Option Expense Disclosures

$$
R_{i t}=\alpha_{0}+\alpha_{1} E_{i t-} V_{R E S O X}+\alpha_{2} \text { DESOX }_{i t}+\alpha_{3} \operatorname{VRESOX}_{i t}+\alpha_{4} O E X_{i t}+\varepsilon_{i t}
$$

\begin{tabular}{|c|c|c|c|c|c|}
\hline $\begin{array}{l}\text { Independent } \\
\text { Variable }\end{array}$ & (1) & (2) & (3) & (4) & (5) \\
\hline Intercept & $\begin{array}{c}0.228 \\
(3.053) \\
\end{array}$ & $\begin{array}{c}0.269 \\
(3.486) \\
\end{array}$ & $\begin{array}{c}0.271 \\
(3.516) \\
\end{array}$ & $\begin{array}{c}0.241 \\
(3.171) \\
\end{array}$ & $\begin{array}{c}0.245 \\
(3.220) \\
\end{array}$ \\
\hline$E_{i t-} V R E S O X_{i t}$ & $\begin{array}{c}0.007 \\
(3.392)^{* * * *}\end{array}$ & $\begin{array}{c}0.008 \\
(3.781)^{* * *}\end{array}$ & $\begin{array}{c}0.008 \\
(3.938)^{* * * *}\end{array}$ & $\begin{array}{c}0.009 \\
(4.288)^{* * * *}\end{array}$ & $\begin{array}{c}0.009 \\
(4.440)^{* * *}\end{array}$ \\
\hline$D_{E S O X}$ & & $\begin{array}{c}-0.344 \\
(-1.917)^{* *} \\
\end{array}$ & $\begin{array}{c}-0.373 \\
(-2.057)^{* *} \\
\end{array}$ & $\begin{array}{c}-0.427 \\
(-2.458)^{* * * *}\end{array}$ & $\begin{array}{c}-0.456 \\
(-2.599) * * * \\
\end{array}$ \\
\hline$V_{R E S O X}$ & & & $\begin{array}{c}-0.073 \\
(-1.101) \\
\end{array}$ & & $\begin{array}{c}-0.074 \\
(-1.161) \\
\end{array}$ \\
\hline$O E X \_M I S E_{i t}$ & & & & $\begin{array}{c}-0.003 \\
(-1.319)^{*}\end{array}$ & $\begin{array}{c}-0.003 \\
(-1.409)^{*}\end{array}$ \\
\hline$O E X \_R D E_{i t}$ & & & & $\begin{array}{c}0.053 \\
(4.138)^{* * *} \\
\end{array}$ & $\begin{array}{c}0.053 \\
(4.117)^{* * * *} \\
\end{array}$ \\
\hline $\begin{array}{l}\text { Number of } \\
\text { Observations }\end{array}$ & 202 & 202 & 202 & 202 & 202 \\
\hline Adjusted $R^{2}(\%)$ & 4.97 & 6.22 & 6.32 & 13.43 & 13.59 \\
\hline
\end{tabular}




\section{Notes:}

Sample is for 202 Canadian S\&P/TSX composite index firms for year 2003.

T-statistics for one-tailed tests are in parentheses.

$*, * *, * * *$ significant at the $0.01,0.05$ and 0.10 level (one-tailed), respectively.

Variables are defined as follows:

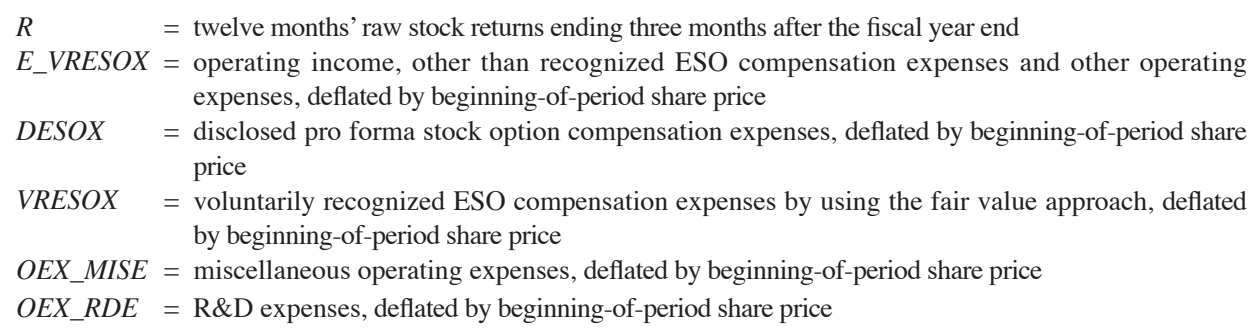

\subsection{Test of Information Content of Recognition Based on the New Reporting Require- ment}

To examine the market valuation of the recognition of compensation expenses related to stock option grants under the expensing rules required by HB 3870, we hand collect all the compensation expenses recognized based on the fair value approach from firms' financial statements for the years 2004-2005. ${ }^{5}$ Sample statistics for 366 firm-year observations are presented in Table 4.

For comparison purposes, Panel A of Table 4 shows selected raw data for the sample firms. As expected, the sample firms are generally large, with a median market capitalization of $\$ 2,205$ million, and a median operating income of $\$ 250$ million. On average, sample firms recognize stock option expenses of \$25 million. Unreported statistics show that in 2004, firms recognized a median of $\$ 3.1$ million of stock option expenses, while in 2005 the median was reduced to $\$ 1.45$ million. This finding is consistent with the observation from prior research (e.g. Carter et al., 2007) that firms reduce the use of stock options and increase the use of other compensation tools, such as restricted stocks, following the unfavorable accounting treatment in the post SarbanesOxley Act era.

Panel B of Table 4 presents the descriptive statistics for the regression variables used in equation (4). Sample firms have an average stock return of 0.184 , which is lower than that in the 2003 sample, an operating income of 25.242 , other operating expenses of 22.181 and $R \& D$ expenses of 0.627 during the sample period, which are comparable to the corresponding numbers in 2003. The recognized ESO costs are 0.493, which is significantly higher than that in the 2003 sample (0.184).

The correlation matrix for regression variables used to estimate equation (4) is presented in Panel C of Table 4. As shown in Panel C, there is a strong positive

\footnotetext{
${ }^{5}$ Despite the requirement, 19 firms in 2004 and 2 firms in 2005 don't adopt the fair value approach and thus report no compensation expenses related to stock options. In such cases, we treat these firms' recognized expenses as zero. Eliminating these sample firms does not affect our inferences significantly.
} 
association between the earnings measure and the stock market annual returns, consistent with extant literature. Interestingly, the correlation between market returns and measure of recognized stock option expenses at the univariate level is significant (recall this correlation is not significant in Table 2). This finding suggests that the market assigns a positive valuation coefficient to recognized ESO compensation expenses under the new accounting requirement. The positive valuation coefficient may be interpreted as follows: granting ESOs under the new accounting requirement mitigates the dilutive effect of stock options and the perceived accounting manipulation due to excessive use of the option plan. Because of this positive effect, recognized ESO expenses are able to highlight the incentive impact of stock option plans on firm performance, and thus provide a favorable signal to the market about a firm's overall value.

Table 4

Descriptive Statistics: 2004-2005 Sample

Panel A: Descriptive Statistics for Selected Raw Data for Year 2004-2005 Sample Firms (in Millions CAN\$)

\begin{tabular}{lccccc}
\hline Variable & Mean & Median & Std. Dev. & $25 \%$ & $75 \%$ \\
\hline OPIN & 862.980 & 250.58 & 1468.3 & 72.038 & 826.95 \\
\hline$B L V$ & 25.532 & 2.321 & 213.30 & 0.919 & 7.474 \\
\hline$M I S E$ & 840.64 & 0.000 & 2902.9 & 0.000 & 199.62 \\
\hline$R D E$ & 24.394 & 0.000 & 180.79 & 0.000 & 0.000 \\
\hline$M V$ & 6710.5 & 2205.3 & 10681.0 & 1057.2 & 5761.9 \\
\hline
\end{tabular}

Panel B: Descriptive Statistics for Regression Variables Used in Equation (4)

\begin{tabular}{lccccc}
\hline \multicolumn{1}{c}{ Variable } & Mean & Median & Std. Dev. & $25 \%$ & $75 \%$ \\
\hline Ret & 0.184 & 0.157 & 0.472 & -0.154 & 0.412 \\
\hline$E$ & 25.242 & 10.834 & 33.475 & 3.795 & 32.580 \\
\hline RESOX & 0.493 & 0.124 & 1.160 & 0.039 & 0.406 \\
\hline OEX_MISE & 22.181 & 0.000 & 60.396 & 0.000 & 13.067 \\
\hline OEX_RDE & 0.627 & 0.000 & 2.170 & 0.000 & 0.000 \\
\hline
\end{tabular}

Panel C: Correlation Matrix of Regression Variables

\begin{tabular}{lccccc}
\hline \multicolumn{1}{c}{ Variable } & Ret & $E$ & RESOX & OEX_MISE & OEX_RDE \\
\hline Ret & 1 & $0.331^{*}$ & $0.132^{* *}$ & 0.081 & $0.119^{* *}$ \\
\hline$E$ & $0.397^{* * *}$ & 1 & $0.231^{* * *}$ & 0.071 & -0.069 \\
\hline RESOX & $0.309^{* * *}$ & $0.418^{* * *}$ & 1 & $0.117 * * *$ & -0.026 \\
\hline OEX_MISE & $0.236^{* * *}$ & $0.381^{* * *}$ & $0.276^{* * *}$ & 1 & $0.508^{* * *}$ \\
\hline OEX_RDE & $0.203^{* * *}$ & 0.021 & $0.161^{* *}$ & $0.205^{* * *}$ & 1 \\
\hline
\end{tabular}

Notes:

Sample is for 366 Canadian S\&P/TSX composite index firm-year observations for the years 2004-2005. 
Pearson correlations are presented in the lower diagonal and Spearman correlations are presented in the upper diagonal.

$*, * *, * * *$ significant at the $0.01,0.05$ and 0.10 level (two-tailed), respectively.

Variables are defined as follows:

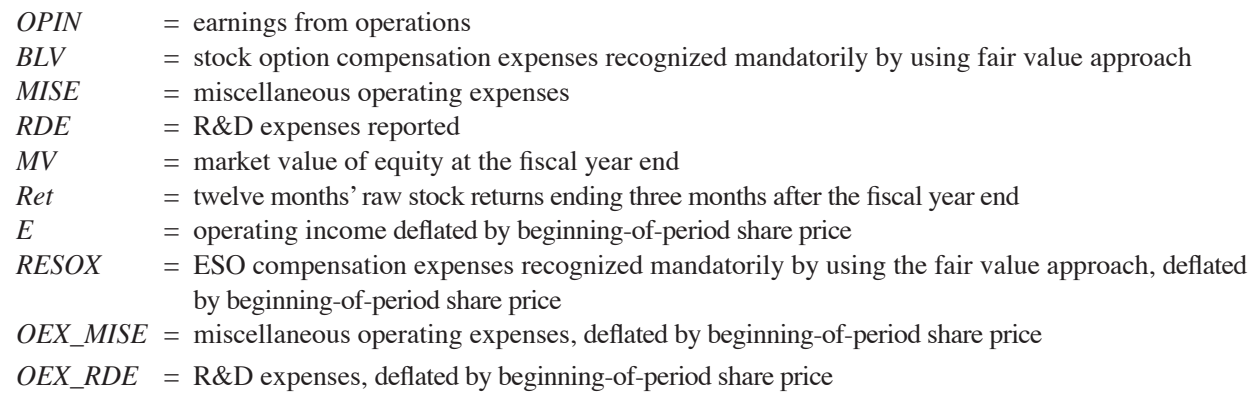

Regression estimates from estimating equation (4) are reported in Table 5. Once again, we initially run the basic model, as shown in column (1), and estimate more complete models, as shown in columns (2)-(6). Across all model specifications, as expected, the coefficient on the measure of operating income is positive and statistically significant at the $1 \%$ level. In addition, when we add the measure of recognized option expenses (RESOX) in the model, the coefficient on RESOX is also positive and significant at the $1 \%$ level, except for model (6). Recall that prior to the expensing requirement, we find that for firms that voluntarily expense stock options, the market generally does not react significantly negatively to the ESO expenses that are recognized voluntarily. The evidence presented in Table 5 seems to suggest that, contrary to the results prior to the tightened accounting rules, the stock market now treats the recognized ESO expenses under the new regulation rule as an asset; thus, it assigns a positive weight to the recognized amount in market valuation. We interpret this result as suggesting that the accounting regulation does improve the financial reporting quality, and as a result, the market appreciates the incentive effect of option plans on firm performance, and thus reacts positively to the expense recognition.

Table 5 shows that the coefficient on R\&D expenses is again positive and significant, which is consistent with the results for the 2003 sample. In contrast, the coefficient on other operating expenses is consistently negative. Overall, the results indicate that the stock market reacts favorably to expenses incurred with potential intangible performance benefits.

To examine whether firm growth potential, firm size and industry affiliation have any impact on the observed results, we partition the sample firms by industry, growth potential and firm size. We allow the proxy for industry $(I N D U)$, growth $(G R O W)$ and firm size (SIZE) to be interacted with the measure of stock option expenses (RESOX) and add the interactive variables as separate independent variables in the regression. Based on the sample partition criterion described in the research design section, we classify 90 firm-years as high tech or financial institutions. Results in columns (4)-(6) suggest that the market valuation of recognized ESO expenses does not change significantly with 
respect to industry affiliation and growth prospects. However, when we add the firm size interactive variable into the regression, it is significantly associated with market returns at the $10 \%$ level, and the RESOX variable, although still positive, becomes insignificant. This suggests that the positive valuation impact of recognition of stock option expenses primarily appears in large sample firms.

\section{Table 5}

\section{Test of Market Valuation of Stock Option Expenses Recognition}

$$
\begin{aligned}
R_{i t}= & \alpha_{0}+\alpha_{1} E_{i t-} \text { RESOX }_{i t}+\alpha_{2} \text { RESOX }_{i t}+\alpha_{3} \text { RESOX }_{i t} * G R O W \\
& +\alpha_{4} \text { RESOX }_{i t} * \operatorname{SIZE}+\alpha_{5} \text { RESOX }_{i t} * I N D U+\alpha_{6} \text { OEX }_{i t}+\varepsilon_{i t}
\end{aligned}
$$

\begin{tabular}{|c|c|c|c|c|c|c|}
\hline $\begin{array}{l}\text { Independent } \\
\text { Variable }\end{array}$ & (1) & (2) & (3) & (4) & (5) & (6) \\
\hline Intercept & $\begin{array}{c}0.043 \\
(1.517) \\
\end{array}$ & $\begin{array}{c}0.034 \\
(1.212) \\
\end{array}$ & $\begin{array}{c}0.013 \\
(3.435) \\
\end{array}$ & $\begin{array}{c}0.013 \\
(0.467) \\
\end{array}$ & $\begin{array}{c}0.014 \\
(0.478) \\
\end{array}$ & $\begin{array}{c}0.027 \\
(0.915) \\
\end{array}$ \\
\hline$E_{i t \_} R E S O X_{i t}$ & $\begin{array}{c}0.006 \\
(8.244)^{* * * *} \\
\end{array}$ & $\begin{array}{c}0.005 \\
(6.197)^{* * *} \\
\end{array}$ & $\begin{array}{c}0.005 \\
(5.885)^{* * * *} \\
\end{array}$ & $\begin{array}{c}0.004 \\
(5.825) * * * \\
\end{array}$ & $\begin{array}{c}0.004 \\
(5.771)^{* * * *} \\
\end{array}$ & $\begin{array}{c}0.004 \\
(4.972)^{* * *} \\
\end{array}$ \\
\hline $\operatorname{RESOX}_{i t}$ & & $\begin{array}{c}0.071 \\
(3.332)^{* * *} \\
\end{array}$ & $\begin{array}{c}0.056 \\
(2.621)^{* * *} \\
\end{array}$ & $\begin{array}{c}0.071 \\
(2.194)^{* *} \\
\end{array}$ & $\begin{array}{c}0.055 \\
(2.429)^{* * *} \\
\end{array}$ & $\begin{array}{c}0.007 \\
(0.109) \\
\end{array}$ \\
\hline$O E X \_M I S E_{i t t}$ & & & $\begin{array}{c}0.000 \\
(0.826) \\
\end{array}$ & $\begin{array}{c}0.000 \\
(0.845) \\
\end{array}$ & $\begin{array}{c}0.000 \\
(0.817) \\
\end{array}$ & $\begin{array}{c}0.000 \\
(0.746) \\
\end{array}$ \\
\hline$O E X_{-} R D E_{i t}$ & & & $\begin{array}{c}0.036 \\
(3.435)^{* * *} \\
\end{array}$ & $\begin{array}{c}0.036 \\
(3.450)^{* * *} \\
\end{array}$ & $\begin{array}{c}0.035 \\
(3.223)^{* * * *} \\
\end{array}$ & $\begin{array}{c}0.034 \\
(3.162) * * * \\
\end{array}$ \\
\hline $\begin{array}{l}\text { RESOX }_{i t}{ }^{*} \\
\text { GROW }\end{array}$ & & & & $\begin{array}{c}-0.022 \\
(-0.617) \\
\end{array}$ & & $\begin{array}{c}-0.010 \\
(-0.245)\end{array}$ \\
\hline $\begin{array}{l}\text { RESOX }{ }_{i t}^{*} \\
\text { SIZE }\end{array}$ & & & & & & $\begin{array}{c}0.069 \\
(1.236) *\end{array}$ \\
\hline $\begin{array}{l}R E S O X_{i t}{ }^{*} \\
I N D U\end{array}$ & & & & & $\begin{array}{c}0.008 \\
(0.178) \\
\end{array}$ & $\begin{array}{c}0.003 \\
(0.066) \\
\end{array}$ \\
\hline $\begin{array}{l}\text { Number of } \\
\text { Observations }\end{array}$ & 366 & 366 & 366 & 366 & 366 & 366 \\
\hline Adjusted $R^{2}(\%)$ & 15.5 & 17.8 & 20.4 & 20.3 & 20.2 & 20.2 \\
\hline
\end{tabular}

\section{Notes:}

Sample is for 366 Canadian S\&P/TSX composite index firm-year observations for the years 2004-2005.

T-statistics for one-tailed tests are in parentheses. *, **, *** significant at the $0.01,0.05$ and 0.10 level (onetailed).

Variables are defined as follows:

$R \quad=$ twelve months' raw stock returns ending three months after the fiscal year end

$E \_R E S O X=$ operating income, other than recognized ESO compensation expenses and other operating expenses, deflated by beginning-of-period share price

RESOX = ESO compensation expenses recognized mandatorily by using the fair value approach, deflated by beginning-of-period share price

$O E X \_M I S E=$ miscellaneous operating expenses, deflated by beginning-of-period share price 


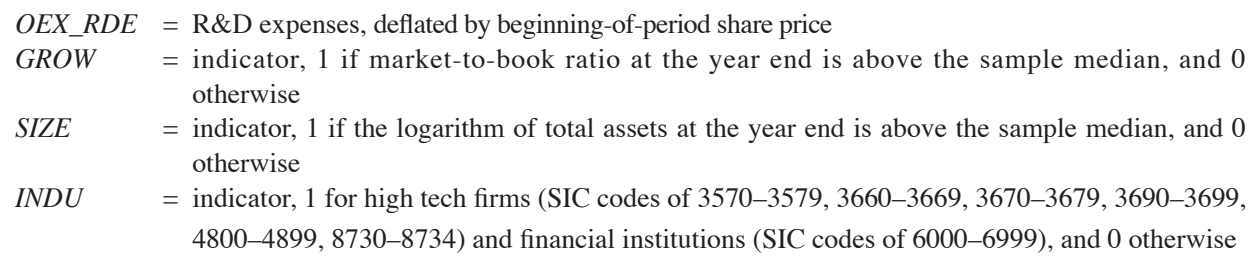

We also conduct other sensitivity tests. For example, considering that 2004 is the first year of the implementation of the new expensing rule, we estimate equation (4) separately for 2004 and 2005, to see whether the results hold across years. Although the interactive variable of RESOX* SIZE based on the 2005 sample is more significant than that based on the 2004 sample, our overall inferences are not affected by this sample partition. We also eliminate firms that do not adopt fair value accounting for ESOs despite the requirement, and re-estimate equation (4). The results are very similar to those reported in Table 5.

\section{Conclusions}

This paper examines the market valuation of stock option expenses recognized by using the recognition rules under the Canadian reporting standard (CICA HB section 3870). We examine two research questions. We initially ask whether investors' response to stock-based compensation expenses depends on where this information is placed disclosure or formal recognition on the income statements. We next investigate whether there is any incremental information content related to the recognition of ESO expenses under the reporting requirement of HB 3870.

Based on a sample of Canadian public firms traded on TSX in the year 2003, prior to the mandatory expensing requirement, we find that pro forma disclosures of compensation expenses are negatively associated with the market value. The result suggests that the pro forma disclosures are value relevant, which is consistent with prior studies (e.g. Aboody et al., 2004b). However, the market generally interprets these expenses as a type of expenditure, perhaps due to the dilutive effect of option grants and the perception that financial reporting quality is compromised because of the manipulative use of stock option plans, which have a negative impact on firm value. In addition, we find that in a valuation framework the coefficient on the voluntarily recognized ESO expenses, although still negative, is not significantly different from zero. We conclude that voluntary recognition of stock option expenses for firms that choose to adopt the fair value approach before the mandatory requirement, to some extent mitigates the negative perception of stock options on firm valuation. The evidence suggests that investors do react differently depending on where the accounting information is presented in the financial statement.

To provide further insight into whether the mandatory expensing rule does enhance financial reporting quality, we investigate the value relevance of the recognition of compensation expenses after the implementation of HB 3870, in 2004 and 2005. Contrary to the results prior to the expensing rule, we find that recognized compensation 
expenses are positively associated with stock returns; the results are even more significant for larger firms. Thus, ESO expenses are no longer treated as an expense but instead are treated as an intangible capital. Overall, the evidence suggests that the mandatory expensing of ESOs increases the perceived quality of financial statements and mitigates the perception that firms use stock options opportunistically. Consequently, the market is able to translate the incentive effect of ESOs into firm value efficiently.

Our study contributes to two streams of research in the literature. First, we contribute to research on recognition versus disclosures of accounting items. Prior studies investigate implications of recognition versus disclosures in different settings (DavisFriday et al., 1999; Ahmed et al., 2006). We contribute to this literature by demonstrating that, prior to and after the mandatory recognition requirement, recognition does matter in firm valuation, and mandatory expensing of ESOs enhances the market valuation of the intangible effect of ESOs as reflected in recognized ESO costs. We also contribute to studies on accounting for ESOs. Prior studies examine the market valuation of disclosures of ESO expenses (Aboody, 1996; Aboody et al., 2004b), or voluntary recognition of ESO expenses under FAS148 (Balsam et al., 2006). Our study, to our knowledge, is the first one to use the recognized ESO expense data under the mandatory expensing requirement, and thus we shed light on an important financial reporting issue more directly.

Finally, our findings provide timely feedback to the standard setters. Given that standard bodies have mandated the income statement recognition of stock-based compensation expenses, our evidence suggests that a tightened mandatory expensing requirement improves the ability of financial statement numbers to explain stock market returns; thus, financial reporting quality is enhanced.

\section{References}

Aboody, D., 1996, "Market valuation of employee stock options", Journal of Accounting and Economics 22, 357-391.

Aboody, D., M. Barth and R. Kasznik, 2004a, "Firms' Voluntary Recognition of Stockbased Compensation Expense", Journal of Accounting Research 42(2), 123-150.

Aboody, D., M. Barth and R. Kasznik, 2004b, SFAS 123 stock-based compensation expense and equity market values", The Accounting Review 79(2), 251-275.

Aboody, D., M. Barth and R. Kasznik, 2006, "Do Firms Manage Stock-based Compensation Expense Disclosed under SFAS 123?", Review of Accounting Studies 11(4), 429-461.

Ahmed, A. S., E. Kilic and G. J. Lobo, 2006, "Does Recognition Versus Disclosure Matter? Evidence from Value-relevance of Banks' Recognized and Disclosed Derivative Financial Instruments", The Accounting Review 81(3), 567-588.

Balsam, S., E. Bartov and J. Yin, 2006, "Disclosure Versus Recognition of Option Expense: An Empirical Investigation of SFAS No. 148 and Stock Returns", working paper, Temple University.

Balsam, S., H. Mozes and H. Newman, 2003, "Managing Pro Forma Stock Option Expense under SFAS No. 123", Accounting Horizons 17, 31-45. 
Balsam, S., A. Reitenga and J. Yin, 2008, "Option Acceleration in Response to SFAS 123(R)", Accounting Horizons 22(1), 23-45.

Bartov, E. and C. Hayn, 2008, "Change in Investor Sentiment Regarding Stock Option Accounting”, working paper, New York University.

Bernard, V. and K. Schipper, 1994, "Recognition and Disclosure in Financial Reporting", working paper, University of Michigan and University of Chicago.

Carter, M.E., L. Lynch and I. Tuna, 2007, "The Role of Accounting in the Design of CEO Equity Compensation", The Accounting Review 82, 327-357.

Chan, L. K., J. Lakonishok and T. Sougiannis, 2001, "The Stock Market Valuation of Research and Development Expenditures", Journal of Finance 6, 2431-2456.

Choudhary, P., S. Rajgopal and M. Venkatachalam, 2009, "Accelerated Vesting of Employee Stock Options in Anticipation of FAS 123-R”, Journal of Accounting Research 47(1), 105-146.

Core, J., W. Guay and S. P. Kothari, 2002, “The Economic Dilution of Employee Stock Option: Diluted ESP for Valuation and Financial Reporting", The Accounting Review 77(3), 627-652.

Davis-Friday, P.Y., C. Liu and H. F. Mittelstaedt, 1999, "The Value Relevance of Financial Statement Recognition vs. Disclosure: Evidence from SFAS No. 106", The Accounting Review 74(4), 403-423.

Dechow, P. M., A. P. Hutton and R. G. Sloan, 1996, "Economic Consequences of Accounting for Stock-based Compensation”, Journal of Accounting Research 34 (Supplement), 1-20.

Espahbodi, H., P. Espahbodi, Z. Rezaee and H. Tehranian, 2002, "Stock Price Reaction and Value Relevance of Recognition Versus Disclosure: The Case of Stock-based Compensation", Journal of Accounting and Economics 33(3), 343-373.

Ferri, F., G. Markarian and T. Sandino, 2005, "Stock Options Expensing: Evidence from Shareholders' Votes”, working paper, Harvard Business School.

Hill, N., S. Shelton and K. Stevens, 2002, "Corporate Lobbying Behavior on Accounting for Stock-Based Compensation: Venue and Format Choices", Abacus 38, 78-90.

Imhoff, E., R. Lipe and D. Wright, 1993, "The Effects of Recognition Versus Disclosure on Shareholder Risk and Executive Compensation", Journal of Accounting, Auditing and Finance 8(4), 335-368.

Imhoff, E., R. Lipe and D. Wright, 1995, "Is Footnote Disclosure an Adequate Alternative to Financial Statement Recognition?", Journal of Financial Statement Analysis 1(Fall), 70-81.

Johnston, D., 2006, "Managing Stock Option Expense: The Manipulation of Optionpricing Model Assumptions", Contemporary Accounting Research 23(2), 395-425.

Klassen, K. and A. Mawani, 2000, “The Impact of Financial and Tax Reporting Incentives on Option Grants to Canadian CEOs", Contemporary Accounting Research 17(2), 227-262.

Lev, B. and T. Sougiannis, 1996, "The Capitalization, Amortization, and Value-relevance of R\&D”, Journal of Accounting and Economics 21(1), 107-138.

Lev, B. and T. Sougiannis, 1999, "Penetrating the Book-to-market Black Box: The R\&D Effect", Journal of Business Finance and Accounting 26(3/4), 419-450. 
Li, H., 2003, "Employee Stock Options, Residual Income Valuation, and Stock Price Reaction to SFAS Footnote Disclosures", working paper, University of Iowa.

Mawani, A., 2003, “Tax Deductibility of Employee Stock Options”, Canadian Tax Journal 51(4), 1230-1258.

McFarland, J., 2002, "Options Put Stock Holdings at Risk", The Globe and Mail, October 11, B1. 
